\title{
Beyond employability skills: Developing professional purpose
}

\author{
Glen W. Bates ${ }^{1}$, Andrew Rixon ${ }^{1}$, Angela Carbone ${ }^{1}$ and Christopher Pilgrim ${ }^{1}$ \\ gbates@swin.edu.au; arixon@swin.edu.au; acarbone@swin.edu.au; cpilgrim@swin.edu.au
}

Corresponding author: Angela Carbone

'Swinburne University of Technology

\begin{abstract}
Rapid transformation of the workplace and a highly competitive labour market has changed the nature of graduate employability. In addition to discipline related knowledge, students now need to be proactive and adaptable in identifying career opportunities. This paper presents a conceptual model that views employability as determined by an overarching professional purpose mindset. This mindset reflects a person's commitment to developing a professional future aligned to personal values, professional aspirations and societal outlook. Four specific mindsets are encapsulated within professional purpose (curiosity, collaboration, action and growth) and relate to three domains of development (self and social awareness; navigating the world of work and networks). Two studies were conducted to explore the professional purpose model. Study one was a qualitative study in which 33 undergraduate students (19 female; 14 male) explored their career decision making. Focus group and interview data showed that each of the four positive mindsets operated in many students' proactive career related behaviours. However, for other students, alternative mindsets negatively influenced their career related behaviour. In the second study, 42 academics (28 male; 14 female) identified unit learning outcomes in existing curricula related to the three domains of development. All domains were evident but outcomes for navigating the world of work received most emphasis. Implications of the findings for further development of the professional purpose model are discussed.
\end{abstract}

Keywords: professional purpose, human and social capital, employability skills, domains of development, mindsets

\section{Introduction: Changing ideas about employability}

The contemporary labour market has become intensely competitive making it extremely difficult for people to find and maintain employment, especially in the period immediately after completing university studies (Tomlinson, 2012; Helyer \& Lee, 2014; Clarke, 2018). The current labour market is also highly turbulent and made unpredictable by corporate restructuring, the gig economy, the creation and removal of specific types of jobs, and outsourcing, to name a few (Smith, 2010). These changing patterns of working life increase career uncertainty and place responsibility on the individual to manage their own career (Clements \& Kamau, 2017; Smith, 2010). People need to be able to adapt to changing job requirements and negotiate a range of role transitions throughout their careers and within the organisations in which they work (Fugate, Kinicki, \& Ashforth, 2004).

The prevailing economic climate has had a profound impact on educational practices within higher education institutions. Changes in government policy, the requirements of employers and of potential students place the onus on universities to develop graduates who have the 
flexibility, resilience, skills and capabilities to succeed in the market and to meet the needs of employers (Hinchcliffe \& Jolly, 2011; Tomlinson, 2012). In responding to this concern, universities face the problem that current curricula focus on disciplinary knowledge at the expense of the multidisciplinary and transferrable skills which help students adapt to the requirements of their working life (Kinash, Crane, Judd, \& Knight, 2016). Universities have adopted two main strategies to address this problem (Clarke, 2018). These include: embedding transferrable skills within curricula linked to graduate attributes (e.g., communication skills, teamwork, complex problem solving) and incorporating opportunities for work experience within courses (e.g., internships, placements, international study tours or exchanges). However, the emphasis on skills development to enhance graduate employability has been criticised as too narrow and insufficient to capture the full complexity of the task of preparing students for their working life (Clark, Zucas, \& Lent, 2011; Jackson, 2016). A largely separate body of literature has emerged in parallel to the more skills based literature. This approach emphasises the importance of developing the individual's capacity to manage their own career and stresses the role of graduates' levels of self-awareness, confidence and adaptability in determining their employability (Clarke, 2018; Holmes, 2013; Jackson, 2016).

There is evidence that graduates' career-related behaviours and attitudes influence their career outcomes. As Clements and Kamau (2017) found, university students who commit to clear career-related life goals during their studies are best able to adopt and maintain proactive career behaviours that enhance their employability after graduation. Such proactive career management includes exploring relevant job options, setting career related goals, developing career relevant skills and abilities, accumulating experiences that ensure future employability and network building (Briscoe, Hall, \& de Muth, 2006; Strauss, Griffen, \& Parker, 2012). Yet, surprisingly, many students do not engage in proactive career behaviours until late in their courses (Tymon, 2013). The challenge for higher education providers, therefore, is how to intervene to assist students to identify personally meaningful career opportunities and to practice proactive career behaviours while at University which complement their skill development.

Theorists who conceptualise the construct of employability as person-centred (e.g., Fugate, et al., 2004; Donald, Baruch, \& Ashleigh, 2017) identify the individual as an active agent in the workplace and in the job search process. According to Fugate et al. (2004), employability is a form of work specific active adaptability that enables workers to identify and realise career opportunities (p.16). They identify three characteristics of employability: career identity, personal adaptability and social and human capital. Within this triad, career identity provides the direction and energy for adaptability and the use of accumulated social and human capital. Although the term career identity is difficult to define, Trede, Macklin and Bridges (2012) identified three distinctive aspects of professional identity as the process of identifying with a specific professional group (e.g., lawyers, accountants, nurses); developing knowledge, skills and values identical to members of that profession and seeing oneself as different to people outside that profession. Once established, a career identity provides a distinct source of motivation for career choices based on the person's desired future and enhances the person's capacity to be proactive in setting life goals to create desired career outcomes. The problem with this model of specific career identities, however, is that in the modern work force many graduates do not work in their chosen professions and need to form an identity that is more generalised (Trede et al., 2012).

Hall introduced the construct of the 'protean career' as an important aspect of career identity (Hall, 1976; 1996; 2002) that reflects how graduates can adapt to the need for flexibility in career identity. The protean careerist is one who can revise and adapt his or her abilities to fit the requirements of the work environment and thereby maintain employability during periods of change. Career moves then become based on the person's own values and life goals. This 
identity is often accessible as a personal narrative or story that captures past, present and future career experiences shaped by underlying motives (Fugate et al., 2004) and less defined by a single professional outcome.

In this paper we suggest that the formation of a broader based career identity and the development of personal adaptability and the human and social capital needed for career success depends upon the higher level, overarching construct of purpose in life. McKnight and Kashdan (2009) defined purpose in life as a central, self-organising life aim that organises and stimulates goals, manages behaviours and provides a sense of meaning (p.242). Purpose thus operates as a superordinate goal manager. The sense of purpose is not linked to the achievement of a designated goal but operates as a mindset motivating the person to be oriented toward goals (Elliott, 2006). Having a purpose in life allows the person to pursue multiple goals and to generate new goals once a goal is attained and thereby to promote personal growth. In contrast, having a specific goal that is not based on a sense of purpose makes new goals hard to identify after the goal is reached and this makes it difficult to sustain the energy needed to pursue a goal (McKnight \& Kashdan, 2009).

\section{The concept of a professional purpose mindset}

Building on the model provided by McKnight and Kashdan (2009), in this study we introduce the term 'Professional Purpose' to represent a career specific form of purpose in life. Professional Purpose is the driver of the development and pursuit of career related goals related to a general career identity. Professional Purpose reflects a person's level of commitment to developing a professional future aligned to their personal values, professional aspirations and societal outlook. Interacting with learning experiences, those people who have cultivated this mindset have a strong commitment to goals related to becoming more self and socially aware, more informed about the changing nature of work, more networked, and more focused on career paths meaningful to them.

A distinctive element of our definition of Professional Purpose is that it operates as a flexible and changeable 'mindset' rather than a fixed disposition. This mindset guides the person's approach to managing the complexity of the work environment. A 'mindset' definition of Professional Purpose represents the understanding that the future work environment and career options cannot be known in advance. In considering models of organisational leadership development, Kennedy, Carroll and Francoeur (2013) argued that the new economy brings into question the fundamental assumption of early models of organisational behaviour that the world is essentially stable and the future knowable. When that assumption is met, a fixed set of skills and competencies can be obtained for employability, or to demonstrate organisational behaviours such as leadership. Relevant skills can be learned and utilised as problems arise. However, because of the uncertainty of career outcomes in contemporary society, the future is not knowable. Thus, skill learning is not sufficient for raising employability in the new economy. What is required is the development of a mindset that can assist the individual to take responsibility for their employability. In this complex environment, Kennedy et al. (2017) argue that change is continuous, self-generating and emergent rather than confined to particular events and extraordinary circumstances. This means life decision-making needs to be based on the person's own worldview, beliefs and values, which generate a search for alternative information to inform the individual's own interpretation of the meaning of events.

The concept of a Professional Purpose Mindset overcomes the limitations of a purely skills based approach to employability. Rhinesmith (1992) identified a mindset as a predisposition to perceive and reason in certain ways (p.63). Under this definition, a mindset fulfils two purposes. The first purpose represented by 'a predisposition to perceive' captures the influence of the person's values and beliefs in giving direction to their life and is linked to their 
motivation to pursue personal goals. The second aspect of 'reasoning' represents the approach the person takes to using this mindset to solve life problems. Taken together, these two aspects of a mindset form the commitment element of Professional Purpose. A Professional Purpose mindset commits the person to developing a professional future aligned to his or her own values and future life aspirations. For a student in higher education, this provides an internalised rationale for their studies to be drawn on to provide motivation and perseverance. A sense of Professional Purpose will thus assist the student to engage with areas of study essential to their studies and their current career direction but not necessarily of immediate interest.

The second aspect of the Professional Purpose mindset concentrates on problem solving and captures the approach the person takes to exploring their options in the workplace. A person with a well-developed Professional Purpose mindset will also be committed to exploring employability opportunities based on an awareness of what they want to achieve in life. This mindset fosters a sense of personal autonomy in career choice rather than a perceived need to conform to a career direction determined by others or the employer. The Professional Purpose mindset also motivates the person to adopt a proactive approach to career management. We argue that such proactive career management is linked to four specific mindsets that are interrelated and encapsulated within a Professional Purpose Mindset. These include: curiosity, collaboration, action and growth, as depicted in Figure 1.

\section{Professional Purpose - four mindsets}

The 'curiosity' mindset is fundamental to Professional Purpose. A recent review of definitions of curiosity in education by Grossnickle (2016) identified four features of what she termed 'epistemic curiosity'. The general term 'epistemic curiosity' was used to cover a range of terms related to intellectual, information seeking and cognitive curiosity that are relevant to educational pursuits and independent of physical and perceptual curiosity. According to Grossnickle, epistemic curiosity constitutes a need to obtain knowledge or information in response to experiencing or seeking out unexpected or puzzling phenomena. The experience of curiosity leads to exploratory behaviour and is usually accompanied by positive emotions. This definition of curiosity is clearly relevant to the proactive career management emanating from the problem solving aspect of the Professional Purpose mindset. A state of curiosity generates exploratory behaviours to gain necessary information, help identify career options and to motivate the person to take action to reduce a sense of uncertainty and fill gaps in knowledge.

The 'action' mindset within Professional Purpose reflects activities sparked by curiosity and which drive employability confidence. Authors who apply design thinking to career development use the metaphor of 'prototyping' to describe key proactive behaviours people engage in to explore their areas of career interest. Burnett and Evans (2016) identify two important types of prototyping behaviour: life design interviewing and prototype experiences. Life design interviewing is used to gather information and ask questions of individuals familiar with the person's areas of career interest or currently working in the field. The interviewee acts as a mentor who shares relevant insights and experiences. That information then informs the person's choice of activities or 'prototype experiences' such as volunteering, shadowing or part-time work and this provides first-hand experience of a job area to inform career direction.

The 'collaboration' mindset captures the use of social networks that drive employability and who can assist the individual in the co-creation of their career (Fugate et al., 2004; Burnett \& Evans, 2016). Using mentors and professional networks is a major source of job opportunities. However, the collaboration mindset is also based on the principle of using feedback and ideas from others that can lead to better decision making and validate personal values and beliefs. Burnett and Evans (2016) argued that discussion with others generates a broader range of ideas and perspectives from which to draw on in seeking out career opportunities and offers 
a useful source of feedback on the individual's own ideas. Liang et al. (2017) identified important others as significant factors in cultivating general life purpose in young university students. Family members, teachers and mentors as well as peers were important sources of affirmation of life purpose and sources of guidance, empowerment and encouragement to take on challenges and act on new opportunities.

The 'growth' mindset complements the other three elements of Professional Purpose by allowing the person to reflect on their purpose and to integrate experiences gained in pursuing their purpose. The growth mindset construct is closely associated with the work of Dweck (2006) who differentiated a 'growth' mindset from a 'fixed' mindset. Based on work in education and self-regulation, the growth mindset is associated with a belief that personality characteristics are changeable and that people are not defined by their past behaviour (Yaeger \& Dweck, 2012). Thus, when adopting a growth mindset, challenging situations, experiences of failure or setback are reframed as opportunities for growth and development. People who believe they can change themselves by their own efforts are more highly motivated to raise their performance and reduce negative traits.

Studies on secondary and tertiary students show a growth mindset is associated with better academic performance and can assist students during their transition to university (Yaeger et al., 2016). A growth mindset is also associated with greater personal resilience, higher work engagement and higher job and life satisfaction (Burnette, O'Boyle, Van Epps, \& Pollack, 2013; Caniels, Semeijn, \& Renders, 2018). The opposite of growth is the 'fixed' mindset. Individuals with a fixed mindset believe that personal traits and behaviour patterns are unchangeable and outside their control. People with a fixed mindset perform less well academically, are less resilient, less able to tolerate errors and more prone to giving up after setbacks (Yaeger \& Dweck, 2012). As a component of Professional Purpose, a growth mindset encourages the individual to explore career options, reflect on their actions and to persevere and make changes after making choices unaligned with their values and interests.

\section{Professional Purpose - Domains of development}

A Professional Purpose mindset determines the person's overarching personal goals and motivation for career development and drives the need to develop personal resources that enable the person to pursue their professional goals. In existent models of employability these resources are referred to as human and social capital (Fugate et al., 2004; Peeters, Nelissen, De Cuyper, Forrier, Verbruggen, \& De Witte, 2017). Based on a review of the literature on sources of human capital relevant to higher education, Donald et al. (2017) identified six forms of human and social capital that can be developed within higher education. These forms of capital include: psychological, scholastic, cultural, market value, skills and social capital. In Professional Purpose, these resources map to three broad 'domains of development' reflected in graduate characteristics. These are 'self and social awareness', the capacity to 'navigate the world of work' and the capacity to 'develop professional networks'.

Within Professional Purpose, the development of 'self and social awareness' and the capacity to 'navigate the world of work' domains appear most influenced by the human capital gained in psychological, scholastic, market value and skills as defined by Donald et al. (2017). Psychological capital overlaps with inner value capital (Baruch \& Peiperi, 2000) and encompasses resources such as confidence, self-awareness, self-efficacy, self-esteem, achievement motivation, optimism and resilience. These resources can be drawn on in making career decisions, setting personal objectives and matching one's abilities and personal qualities to a career. They are also a source of motivation to persevere when challenged. Scholastic, market value and skills capital relate more directly to navigating the world of work. Scholastic capital utilizes the perceived value of one's degree derived from academic experiences and grades whereas market value and skills draw on experiences gained in the labour market through part time work or work integrated learning. Both forms of capital 
contribute to job relevant skills such as communication, leadership and problem solving. They also relate to the development of a professional identity that incorporates the self-awareness present in psychological capital.

The 'broadening professional networks' domain reflects social and cultural capital. Donald et al. (2017) define social capital broadly covering a social network compromised of contacts parents, family, peers, memberships and online communities such as Linkedln. Cultural capital adds accumulated experiences from activities such as travel, extracurricular involvement, leisure activities, volunteering and social media involvement. Both forms of capital provide sources of people who can help identify career opportunities, advise on different careers, assist with career decision making and generate knowledge and experience to be drawn on in the work place.

\section{A conceptual model of Professional Purpose}

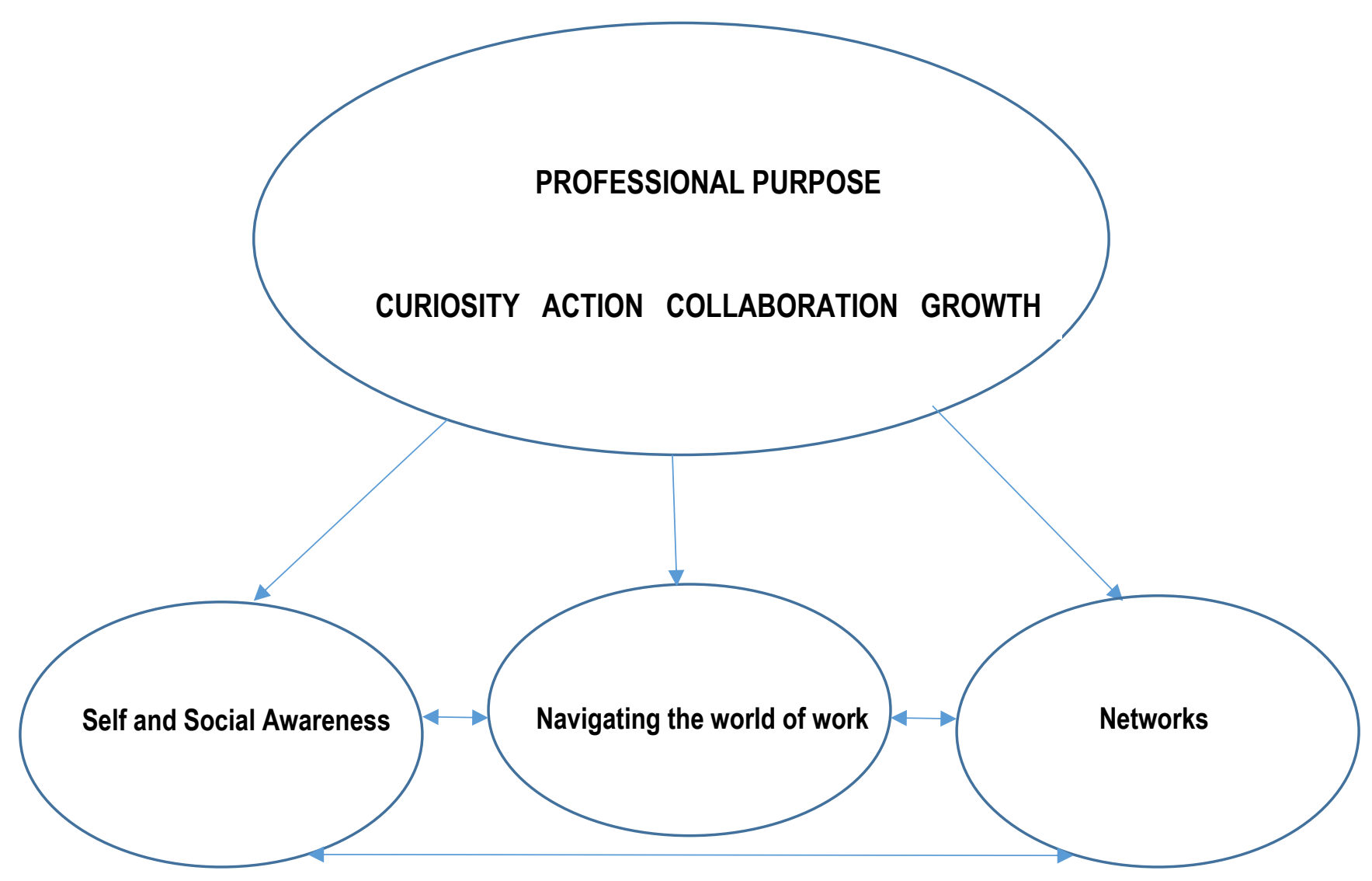

Figure 1: Conceptual Model of Professional Purpose Mindsets and Domains of Development

Figure 1 depicts a conceptual model of how Professional Purpose drives the process of career exploration and the development of career relevant human and social capital. As a general mindset, Professional Purpose includes the person's values and beliefs that sustain their commitment to a professional future and which inform the approach taken toward preparing for the professional future. The specific mindsets of curiosity, action, collaboration and growth then direct exploratory behaviours. As shown in Figure 1, theoretically, the three areas of 
human and social capital development emanate from professional purpose and are interrelated. Thus, development in one area can influence development in the other areas.

\section{The research project}

The present study was an exploratory investigation of the Professional Purpose Model and had two aims related to establishing the existence of the key components of the conceptual model. The first aim was to determine the extent to which the Professional Purpose mindset (curious, collaborative, action, growth) is evident in students' reflections on their career decision making. Aim two was to gauge the presence of the three domains of development in existing curricula. Specifically, the research was guided by two research questions:

- How do students approach career decision-making and is there evidence of the use of a Professional Purpose mindset?

- What evidence is available in our current curricula that supports the presence of the Professional Purpose domains of development?

Consequently, the study involved two concurrent studies: Study 1 and Study 2 . In Study 1 undergraduate students were invited to participate in focus groups followed by in-depth interviews to explore evidence of the Professional Purpose mindset. In Study 2 workshops were conducted inviting academics to examine how the Professional Purpose domains of development were represented in curricula. The research was approved by the Swinburne University Human Ethics Committee (SUHERC) - SHR Project 2018/301.

\section{Study 1: Exploring student mindsets in approaching career decision making}

\section{Participants and procedure}

To explore whether Professional Purpose mindsets are evident in the students' career decision-making, undergraduate students were invited to participate in workshop sessions and some were later followed up with in-depth interviews. In total, four workshops and five in-depth interviews were held. A total of 33 students (19 female, 14 Male) participated in the workshops. Of these 33 students, 22 were domestic and 11 were international. There were more domestic than International students as many International students had returned home over the holidays. The students were roughly equally spread across the university's three faculties. From this pool of students, a random sample of five students (four female and one male) participated in the in-depth interviews. All interviews were conducted on campus and lasted for 45 minutes to an hour.

Students were recruited using campus advertising. Flyers were posted around the campus and electronic versions were uploaded onto Blackboard. Other students were informed about the study by Academic Development Advisors. Students expressed their interest in participating via email/ phone or signed up electronically. As an incentive, they received a $\$ 50$ Coles Myer voucher for their participation time, and were provided with refreshments during the session.

\section{Data collection and thematic analysis}

The student workshops were facilitated by two non-teaching staff who worked in the central university teaching and learning area. Students were asked to complete three activities. The first activity explored students' current study, and whether there was alignment between their career plans as a 12 year old and their future career aspirations. The second activity required students to reflect on factors that influenced their study and career choices and then discuss these influencing factors in small groups. In the final activity students wrote down their 
personal goals and professional goals on post-it notes, and then discussed with their group whether they saw any overlap between the two. Across each activity students were asked to explore ways in which a tertiary institution could influence, guide and support their decision making process. Responses to these activities were recorded and transcribed.

The five students who participated in the follow-up interviews explored their decision-making processes in more depth. The semi-structured interviews focused on three areas: The student's study selection; how the student had explored and refined their career purpose; and what support the student needed to achieve their career purpose. (See Appendix A for the interview guide).

An inductive and deductive approach was taken with the data analysis. A thematic analysis was performed following Braun and Clarke's (2006) step-by-step framework, which comprises of three phases. Phase 1: Familiarising with the data; Phase 2: Generating initial codes (e.g., 'We're here for a job', 'Personal sacrifices to do the course'); Phase 3: Creating themes from the codes; Phase 4: Reviewing themes; and Phase 5: Defining the key themes. A deductive approach was then applied to map the emerging themes and associated codes to the four associated Professional Purpose mindsets.

\section{Results}

Analysis of the data from the workshops and interviews provided evidence of the presence of all the four elements of the Professional Purpose mindset of curiosity, collaboration, action and reflection in the students' career decision making processes. However, students differed in how their mindset influenced their approach and alternative mindsets were apparent for each. Whereas some students used mindsets that were constructive and proactive, others operated according to alternate mindsets that restricted their capacity to be proactive. Data for each mindset is considered in turn and a full list of themes identified for each mindset is presented in Appendix B)

\section{Curiosity mindset}

The student data identified key elements that are evident in the construct of 'curiosity' for each of the three domains of development. These are highlighted in Table 2 as: exploring one's goals and values; exploring career alternatives and industries of interest; and seeking out a range of people in a range of professions to get their perspectives. Comparison of the responses of those using the curiosity mindset with themes emerging from those who did not revealed an alternative mindset to curiosity. Students operating according to the alternative mindset were characterised by an approach to career exploration that was anxious and closed to exploration. This anxiety related to employment outcomes and there was no evidence of any self-reflection or interest in the meaning of work.

The example quotes below illustrate the alternative mindsets. The curiosity mindset identified an approach characterised as open to new experiences, interested and process focussed as evidenced in the following comments:

In relation to our career goals we think about: what do I like, what am I good at; what impact do I want to have, what is a fulfilling career?

I'm working out what a fulfilling job means for me.

The alternative closed mindset included behaviours that could be described as disinterested in new experiences, uncertain, anxious, and narrowly employment outcome focussed:

A major preoccupation for me and many of my friends is whether we will get a job out of our university experience. 
We're not here for the fun of it at $\$ 1300$ a unit. We're here for a job.

Table 1: Professional Purpose: Domains of Development and Mindsets

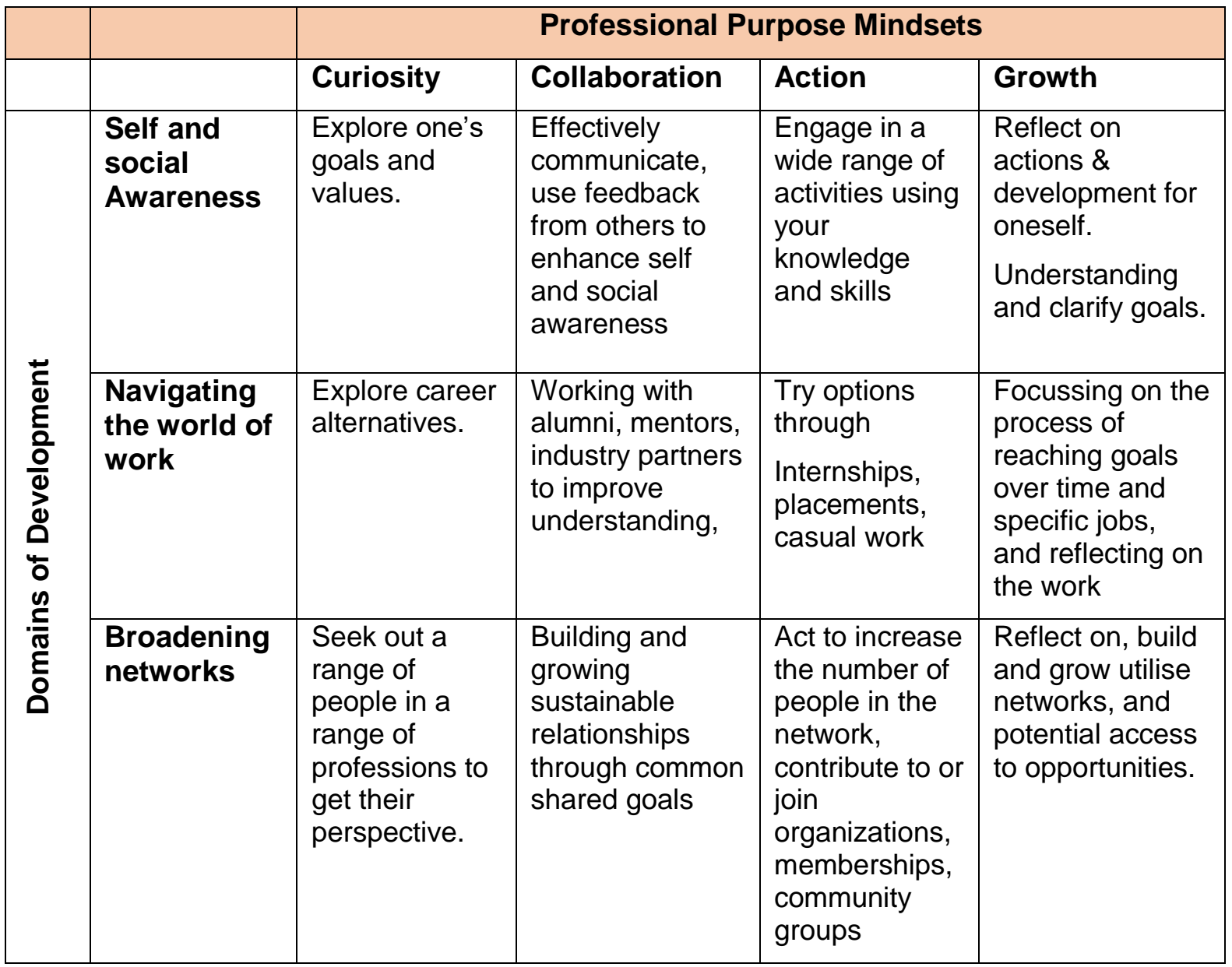

\section{Collaboration mindset}

The key elements of the 'collaboration' mindset were operationalised from the student data in each of the three domains of development as: effectively communicate, use feedback from others to enhance self and social awareness; working with alumni, mentors, industry partners to improve understanding; and building and growing sustainable relationships through common shared goals (see Table 2). As with curiosity, some students exhibited a collaboration mindset whereas others adopted an alternative mindset. Behaviours were described that could be classified as collaborative and networked:

I want to talk to people in industry about their experiences in getting jobs and what happens in their job and the industry.

Industry connections, networking events help shape my understanding of the world of work.

On the other hand, behaviours were identified that reflected feelings of isolation and of being alone and dependent on others to form the networks needed to develop a career:

If you help me connect, I feel more engaged, purposeful and confident.

Bates, G.W., Rixon, A., Carbone, A., \& Pilgrim, C. (2019). Beyond employability skills: Developing professional purpose. Journal of Teaching and Learning for Graduate Employability, 10(1), 7-26. 


\section{Action mindset}

For the 'action' mindset the student data yielded important elements of action for each of the three domains of development. These are highlighted in Table 2 as: engaging in a wide range of activities using your knowledge and skills; trying options through Internships, placements, casual work; and acting to increase the number of people in the network, contribute to or join organizations, memberships, community groups. Once more there was evidence in the data that some students exhibited an action mindset and others did not. For the action mindset we found examples of career related behaviours that were proactive and autonomous:

I was googling, trying to figure out what I was going to do with my degree.

I seek out information and experiences that help me verify that I am on the right path.

The alternative mindset included behaviours that were reactive, dependant and apprehensive:

At the end of the day, we're all here to get a job.

Industry experience can be seen as scary. I know that some of my friends are ready from day one. Others need a gentle push while others need a lot more support.

I need to feel like what I am studying will lead to a fulfilling job.

\section{Growth mindset}

Consistent with Dweck's definition of 'growth' mindset discussed in the introduction (Dweck, 2006), the student data operationalised the key elements of action for each of the three domains of development as: reflecting on actions and development for oneself to understand and clarify goals; focussing on the process of reaching goals over time and specific jobs, and reflecting on the work, organisation, knowledge, skills and personal attributes needed to succeed; and reflecting on utilising networks, and potential access to opportunities (see Table 2).

The participants' responses reflected the 'growth' and alternative 'fixed' perspectives referred to in the literature (Yeager \& Dweck, 2012). For the growth mindset, we found examples of behaviours that could be described as reflective and progress oriented:

There are many times throughout my course when I will reflect whether my current study area will lead to a fulfilling career.

I had to design a brand and logo for a real client in a unit I just finished. I really enjoyed the process. The experience made me start thinking more long-term and really plan my future.

For the alternative fixed mindset we found examples of attitudes that were set but uncertain about the future:

Lecturers have a role in helping students understand the relevance of industry exposure.

Sometimes as a student, you get so caught up in the units in a semester, you start to lose sight of what you're doing it all for.

Bates, G.W., Rixon, A., Carbone, A., \& Pilgrim, C. (2019). Beyond employability skills: Developing professional purpose. Journal of Teaching and Learning for Graduate Employability, 10(1), 7-26. 


\section{Study 2: Evidence of domains of development in curricula}

\section{Participants and procedure}

To determine whether there was evidence of Professional Purpose domains of development in curricula, course directors and general academic staff were invited to map their Course Learning Outcomes (CLOs) and their Unit Learning Outcomes (ULOs) to the three Domains of Development (DoDs). The academics were sourced from lists of course directors for both undergraduate and post-graduate degrees across three faculties of Swinburne University: Faculty of Science, Engineering and Technology (FSET); Faculty of Health, Arts and Design (FHAD); and Faculty of Business and Law (FBL). In total, 42 academics (28 male and 14 female) attended a series of five 1.5 hour workshops (see Table 2). The workshops provided an opportunity to socialise the notion of Professional Purpose, discuss principles for embedding Professional Purpose into the curricula and provide examples of course learning outcomes (CLOs) and unit learning outcomes (ULOs) that were congruent to the domains of development. Following the workshop these were compiled into a spreadsheet of ULO's to enable both qualitative review and descriptive statistical analysis.

Table 2: Number of Participants in the Professional Purpose Workshops

\begin{tabular}{l|l|l|l}
\hline Date & FSET & FBL & FHAD \\
\cline { 1 - 4 } 24 July $(\mathrm{U} / \mathrm{G})$ & 5 & 3 & 1 \\
\hline 10 August $(\mathrm{U} / \mathrm{G})$ & 2 & 5 & 4 \\
\hline 16 August $(\mathrm{P} / \mathrm{G})$ & 2 & 1 & 1 \\
\hline 20 August $(\mathrm{P} / \mathrm{G})$ & 1 & 2 & 6 \\
\hline 21 August $(\mathrm{P} / \mathrm{G})$ & 2 & 4 & 3 \\
\hline Total Participants & $\mathbf{1 2}$ & $\mathbf{1 5}$ & $\mathbf{1 5}$
\end{tabular}

\section{Results}

The academics provided 235 examples (113 Undergraduate \& 122 Postgraduate) of unit learning outcomes that aligned with the three domains of development: 'Self and Social Awareness', 'Navigating the world of work', and 'Building networks'. Table 3 contains representative examples of ULOs across the three domains. 
Table 3: Professional Purpose: Domains of Development and Mindsets

\begin{tabular}{|l|l|l|}
\hline $\begin{array}{l}\text { Professional } \\
\text { Purpose Domains }\end{array}$ & $\begin{array}{l}\text { Example Undergraduate } \\
\text { ULO's }\end{array}$ & Example Postgraduate ULO's \\
\hline $\begin{array}{l}\text { 1. Self and Social } \\
\text { Awareness }\end{array}$ & $\begin{array}{l}\text { Demonstrate the application of } \\
\text { knowledge and skills to } \\
\text { demonstrate autonomy, well- } \\
\text { developed judgment, } \\
\text { adaptability and responsibility. }\end{array}$ & $\begin{array}{l}\text { Demonstrate professionalism, } \\
\text { integrity, ethical conduct, } \\
\text { professional accountability and } \\
\text { awareness of professional practices } \\
\text { in a global and sustainable context. }\end{array}$ \\
\hline $\begin{array}{l}\text { 2. Navigating the } \\
\text { world of work } \\
\text { (wow) }\end{array}$ & $\begin{array}{l}\text { Discuss and critique } \\
\text { contemporary trends, policies } \\
\text { and movements in the } \\
\text { profession within Australia and } \\
\text { internationally. }\end{array}$ & $\begin{array}{l}\text { Demonstrate advanced knowledge } \\
\text { of the different settings forensic } \\
\text { mental health nurses work in and } \\
\text { evaluate how these setting may } \\
\text { impact on practice. }\end{array}$ \\
\hline $\begin{array}{l}\text { 3. Building } \\
\text { Networks }\end{array}$ & $\begin{array}{l}\text { Demonstrate professional } \\
\text { relationships with education } \\
\text { professionals, students and } \\
\text { families. }\end{array}$ & $\begin{array}{l}\text { Demonstrate clear and coherent } \\
\text { communication skills to articulate } \\
\text { complex knowledge and justify } \\
\text { propositions and professional } \\
\text { decisions to specialist and non- } \\
\text { specialist audiences; including } \\
\text { clients, customers, multi- } \\
\text { disciplinary/ multi-cultural project } \\
\text { teams and stakeholders }\end{array}$ \\
\hline
\end{tabular}

Of these 235 ULO examples, Figure 2 illustrates that across undergraduate and postgraduate almost half were related to the Developmental Domain: 'Navigating the world of work'. One third related to 'Self and Social Awareness' and the least represented domain was 'Building Networks' representing only 17 percent (undergraduate) and 26 percent (postgraduate) ULOs.

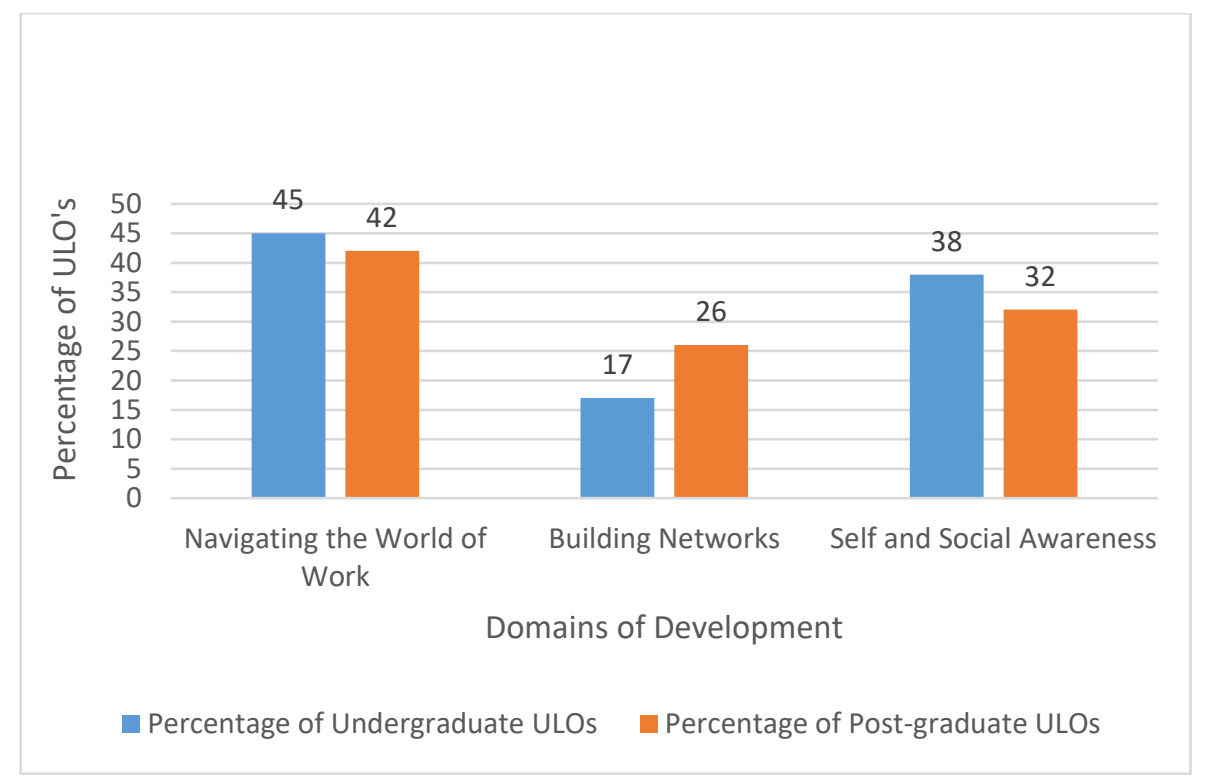

Figure 2: Mapping of Unit Learning Outcomes to Domains of Development

Bates, G.W., Rixon, A., Carbone, A., \& Pilgrim, C. (2019). Beyond employability skills: Developing professional purpose. Journal of Teaching and Learning for Graduate Employability, 10(1), 7-26. 


\section{Discussion}

In this paper, we have developed a conceptual model for exploring the utility of Professional Purpose that relates to the development of graduate employability. The empirical work in the two studies provides initial support for the relevance of the professional purpose mindsets to the ways in which students approach their career thinking (Study 1). The data also show that many existing ULOS are consistent with the domains of development in human and social capital linked to improved employability (Study 2).

The data obtained relating to the students' use of the mindsets encapsulated within professional purpose provide some insight into the reasons not all students can effectively engage in proactive career related behaviours. Our data revealed that for each of the proactive and constructive mindsets that foster the development of professional purpose there is an alternate mindset that restricts such development. The differentiation of a growth from a fixed mindset is well documented in relation to student learning and resilience (e.g., Dweck, 2006, Yeager \& Dweck, 2012; Yeager et al., 2016) and this study shows a similar relationship may exist within career self-management and employability. However, the alternate mindsets identified in the student data provide new insights into the processes involved in effectively enacting a professional purpose. Along with growth, the curious, collaborative and proactive mindsets contrast markedly with mindsets that are fixed, disinterested in change, isolated dependent and reactive. Understanding these different mindsets raises a number of possibilities for future research and has implications for programs seeking to raise employability.

To build on this study a broader investigation is needed to confirm the relevance of the Professional Purpose Model to employability related behaviours of students across the full range of the student community and at different stages of experience in the workplace. Moreover, the interactive nature of the mindsets needs to be explored. For example, the growth and curiosity mindsets may underpin the commitment to action and to collaboration. A student may need to first develop an interest in the world of work and develop a perception that employability is something that can be enhanced before taking action and looking to form networks. The relationship between professional purpose mindsets and the alternate restricting mindsets also warrants attention to establish whether combinations of mindsets exist which contain negative and positive features. These enquiries could inform interventions to promote professional purpose mindsets. A feature of mindsets is that they are malleable (Dweck, 2006) and thus people who are restricted by alternate mindsets can be assisted to alter their thinking and thereby to enhance their employability. A priority for future work is therefore to use the Professional Purpose Model to generate strategies for developing professional purpose mindsets and for overcoming the self-limiting alterative mindsets.

The data collected from academics in Study 2 provide evidence that the three Professional Purpose Domains of Development are represented in existing curricula across undergraduate and postgraduate courses. However, the highest percentage of ULO's was associated with navigating the world of work. This suggests that academics appreciate the importance of this domain in preparing students for the future of work and may reflect the focus in universities on developing transferrable skills within courses (Clarke, 2018). Interestingly, the other domains which capture more general aspects of personal development were less represented in the ULOs. Self and Social Awareness was present in approximately a third of the ULO's analysed. It was articulated almost independently of the discipline and described as students showing autonomy, adaptability, responsibility, professionalism, integrity and ethics. ULOs related to building networks were the least prominent of the domains at 26 percent. These ULOs focused on helping students to build networks that include relationships and connections with professionals and specialists within the discipline. Assisting students to know how to communicate to different audiences was also highlighted. Each of these areas 
are consistent with effective career self-management and the development of career relevant social capital (Donald et al., 2017). Nevertheless, the preponderance of ULOs relevant to navigating the world of work relative to the over self-awareness and building network domains suggests that changes in curriculum design may be needed to build all three types of resources. It also remains to be established how the ULOs linked to the domains of development relate and influence each other.

\section{Methodological considerations}

As an exploratory investigation this study has unearthed data that show the promise of the Professional Purpose Model. However, the research has some limitations. In Study 1, while our sample was appropriate for qualitative analysis, we were unable to examine the operation of the mindsets in different cohorts of students such as part-time or mature age students. Nor could we look at differences in the professional purpose of commencing students as compared to students in later years of their courses. As levels of maturity and work experience are likely to impact on perceived employability, further research is needed to establish how the mindsets operate in different student cohorts. Longitudinal work is also needed to establish how the professional purpose mindset may develop over the student lifecycle. In Study 2, the mapping of ULO's to the Domains of Development by academics is open to individual interpretation, and we did not check for inter-rater reliability as the ULOs considered were identified by the academics. In addition, we were not able to examine all ULOs in the various courses of the University. A full coverage of all ULOs would have allowed us to establish the proportion of the total number of ULOs that related to the DODs and this the degree of coverage of the three DODs. Each of these issues will need to be addressed in future research.

\section{Acknowledgements}

The authors wish to acknowledge the contribution by the members of the Professional Purpose working group, in particular Deb McDonald and Janice Jackson from Student Engagement - Careers and Employability, the leadership provided by Arthur Mellors from the Nous Group and Fiona Fowler for co-ordinating the student workshops and interviews. 


\section{References}

Baruch, Y., \& Peiperi, M. (2000). The impact of an MBA on graduate careers. Human Resource Management Journal, 10(2), 69-90. doi: 10.1111/j.1748-8583.2000.tb00021.x

Braun, V., \& Clarke, V. (2006). Using thematic analysis in psychology. Qualitative Research in Psychology, 3(2), 77-101. doi: 10.1191/1478088706qp063oa

Briscoe, J.P., Hall, D.T., \& De Muth, F. (2006). Protean and boundaryless careers: An empirical exploration. Journal of Vocational Behavior, 69(1), 30-47. doi: https://doi.org/10.1016/j.jvb.2005.09.003

Burnett, B., \& Evans, D. (2016). Designing your life: How to build a well-lived, joyful life. New York: Alfred A. Knopf.

Burnette, J.L., O’Boyle, E.H., Van Epps, E.M., Pollack, J.M., \& Finkel, E.J. (2013). Mind sets matter: A meta-analytic view of implicit theories and self-regulation. Psychological Bulletin, 139(3), 655-701. doi: https://doi.org/10.1037/a0029531

Caniels, M.C.J., Semeijn, J.H., \& Renders, I. H. M. (2018). Mind the mindset! The interaction of proactive personality, transformational leadership and growth mindset for engagement at work. Career Development International, 23(1), 48-66. doi: 10.1108/CDI-11-2016-0194

Clark, M., Zucas, M., \& Lent, N., (2011). Becoming an IT person: Field, habitus and capital in the transition from university to work. Vocations and Learning, 4,133-150

Clarke, M. (2018). Rethinking graduate employability: The role of capital, individual attributes and context. Studies in Higher Education, 43, 1923-1937. Doi:10.1080/03075079.2107.1294152

Clements, A.J., \& Kamau, C. (2018). Understanding students' motivation towards proactive career behaviours through goal-setting theory and the job-demands resources model. Studies in Higher Education, 43(12), 2279-2293. doi: 10.1080/03075079.2017.1326022

Donald, W.E., Baruch, Y., \& Ashleigh, A. (2017). The undergraduate self-perception of employability: Human capital, careers advice, and career ownership. Studies in Higher Education, 44(4), 599-614. doi: https://doi.org/10.1080/03075079.2017.1387107

Dweck, C.S. (2006). Mindset. New York, NY: Random House

Elliott, A. (2006). The hierarchical model of approach-avoidance motivation. Motivation and Emotion, 30(2), 111-116. doi: http://.doi.org/10.1007/s11031-006-9028-7

Fugate, M., Kinicki, A.J., \& Ashforth, B.E. (2004). Employability: A psycho-social construct, its dimensions and applications. Journal of Vocational Behavior, 65(1), 14-38. doi: https://doi.org/10.1016/j.jvb.2003.10.005

Grossnickle, E.M. (2016). Disentangling curiosity: Dimensions, definitions, and distinctions from interest in educational contexts. Educational Psychology Review, 28(1), 23-60. doi: https://doi.org/10.1007/s10648-014-9294-y

Hall, D.T. (1976). Careers in organizations. Glenview IL: Scott, Forseman.

Hall, D.T. (1996). Protean careers of the 21st century. Academy of Management Executive, 10(4), 8-16. doi: https//doi.org/10.5465/ame.1996.3145315

Hall, D.T. (2002). Careers in and out of organizations. Thousand Oaks, CA: Sage.

Helyer, R., \& Lee, D. (2014). The role of work experience in future employability of higher education graduates. Higher Education Quarterly, 68(3), 348-372. doi: https//doi.org/10.1111/hequ.12055

Hinchcliffe, G.W., \& Jolly, A. (2011). Graduate identity and employability. British Educational Research Journal, 37, 563-584.doi: 10.1080/07294360.2016.1139555

Holmes, L. (2013). Competing perspectives on graduate employability: Possession, position or process? Studies in Higher Education, 38, 538-554. Doi:10.1080/03075079.2011.587140

Jackson, D. (2016). Re-conceptualising graduate employability: The importance of preprofessional identity. Higher Education Research and Development, 35, 925-938. Doi:10.1080/07294360.2016.1139551

Kennedy,F., Carroll, B., \& Francoeur, J. (2013). Mindset not skillset: Evaluating in new paradigms of leadership development. Advances in Developing Human Resources, 15(1), 10-26. doi: https://doi.org/10.1177/1523422312466835

Bates, G.W., Rixon, A., Carbone, A., \& Pilgrim, C. (2019). Beyond employability skills: Developing professional purpose. Journal of Teaching and Learning for Graduate Employability, 10(1), 7-26. 
Kinash, S., Crane, L., Judd, M., \& Knight, C. (2016). Discrepant stakeholder perspectives on graduate employability strategies. Higher Education Research and Development, 235, 951967.

Liang, B., White, A., de Silva Mousseau, A., Hasse, A., Knight, L., Berado, D., \& Lund, T.J. (2017). The four P's of purpose among college bound students: People, propensity, passion, prosocial benefits. The Journal of Positive Psychology, 12(3), 281-294. doi: https://doi.org/10.1080/17439760.2016.1225118

McKnight, P.E., \& Kashdan, T.B. (2009). Purpose in life as a system that creates and sustains health and well-being: An integrative, testable theory. Review of General Psychology 13(3), 242-251. doi: https://doi.org/10.1037/a0017152

Peeters, E., Nelissen, J., De Cuyper, N., Forrier, A., Verbruggen, M., \& de Witte, H. (2017). Employability capital: A conceptual framework tested through expert analysis. Journal of Career Development, 20, 1-15. doi: https://doi.org/10.1177/0894845317731865

Rhinesmith, S.H. (1992). Global mindsets for global managers. Training and Development, 46(10), 63-69. Retrieved from http://link.galegroup.com.ezproxy.lib.monash.edu.au/apps/doc/A13528770/AONE?u=monash $\&$ sid $=$ AONE\& $\&$ id $=5 \mathrm{~d} 16 \mathrm{f} 4 \mathrm{e} 3$

Smith, V. (2010). Enhancing employability: Human, cultural and social capital in an era of turbulent unpredictability. Human Relations, 63(2), 279-300. doi: https://doi.org/10.1177/0018726709353639

Strauss K., Griffen, M.A., \& Parker, S.K. (2012). Future work selves: How salient hoped-for identities motivate proactive career behaviours. Journal of Applied Psychology, 97(3), 580 598. doi: https://doi.org/10.1037/a0026423

Tomlinson, M. (2012). Graduate employability: A review of conceptual and empirical themes. Higher Education Policy, 25(4), 407-431. doi: https://doi.org/10.1057/hep.2011.26

Trede, F., Macklin, R., \& Bridges, D. (2012). Professional identity development: A review of the higher education literature. Studies in Higher Education, 37, 365-384. Doi: $10.1080 / 03075079.2010 .521237$

Tymon, A. (2013). The student perspective on employability. Studies in Higher Education, 38(6), 841-856. doi: https://doi.org/10.1080/03075079.2011.604408

Yaeger, D.S., \& Dweck, C.S. (2012). Mindsets that promote resilience: When students believe that personal characteristics can be developed. Educational Psychologist, 47(4), 302-314. doi: https://doi.org/10.1080/00461520.2012.722805

Yaeger, D.S., Romero, C. , Paunesku, D., Hulleman, C.S., Schneider, B., Hinojosa, C., Hae, Y.L., O'Brien, J., Flint, K, Roberts, A., Trott, J., Greene, D., Walton. G.W., \& Dweck, C.S. (2016). Using design thinking to improve psychological interventions: The case of the growth mindset during the transition to high school. Journal of Educational Psychology, 108(3), 374391. doi: https://doi.org/10.1037/edu0000098

Bates, G.W., Rixon, A., Carbone, A., \& Pilgrim, C. (2019). Beyond employability skills: Developing professional purpose. Journal of Teaching and Learning for Graduate Employability, 10(1), 7-26. 


\section{Appendix A: Student workshops interview guide}

\section{Section 1 - Students student selection}

- I'm interested to learn how you chose to study your course at $X Y Z$ and the process you took to make that decision. Include the thoughts and feelings you had at Secondary School

- What were the most challenging aspects about selecting your course?

- When you reflect, what drove your decision making? What and who influenced you?

- Can you talk about the key moments or interactions that helped you make that choice?

\section{Section 2 - How students explore and refine their career purpose}

- How confident are you in your choice? Are you currently considering a change in course? Why or why not? If you are exploring options, what are you exploring and how are you doing so?

- What technology did you use to help you make a decision on your study course?

- Which mobile apps or websites do you use to assist you for your career?

- Who did you, and who do you turn to for advice on study and/or career options? Why?

- What have been your greatest frustrations in seeking help?

\section{Section 3 - Support needed to help students achieve their career purpose.}

- What resources (information, would help you to accelerate your career?

- What questions or concerns do you have regarding your career and finding your career purpose?

- What skills do you think are missing from your current toolset for you to be work ready?

- How will you demonstrate your skillset to employers?

- What do you see as the greatest barriers to gaining your ideal career, post study? What are you currently doing to bridge those gaps?

- How do you know if you are on-track or not? 
Appendix B: Thematic analysis of data collected in Study B

\begin{tabular}{|c|c|c|}
\hline \multirow[b]{2}{*}{$\begin{array}{l}\text { Use of } \\
\text { mindsets } \\
\text { across: } \\
\text { 1. Develop Self } \\
\text { \& Social } \\
\text { Awareness, } \\
\text { 2. Navigate the } \\
\text { World of Work } \\
\text { 3. Broaden } \\
\text { Networks }\end{array}$} & & \\
\hline & \multicolumn{2}{|c|}{$\begin{array}{l}\text { Mindset Continuum } \\
\text { Solution / Outcome focussed vs Process focussed }\end{array}$} \\
\hline \multirow[b]{2}{*}{$\begin{array}{l}\text { Curiosity } \\
\text { 1. Explore one's } \\
\text { goals and } \\
\text { values. } \\
\text { 2. Explore } \\
\text { career } \\
\text { alternatives } \\
\text { and the } \\
\text { industries of } \\
\text { interest. } \\
\text { 3. Seek out a } \\
\text { range of } \\
\text { people in a } \\
\text { range of } \\
\text { professions to } \\
\text { get their } \\
\text { perspective. }\end{array}$} & Closed - uncertain anxious & Open - interested \\
\hline & $\begin{array}{l}\text { "We're not here for the fun of it at } \\
\$ 1300 \text { a unit. We're here for a job" } \\
\text { "In some lectures, the guest } \\
\text { speaker come in for the last } 10 \\
\text { minutes and half the class walked } \\
\text { out - the content wasn't seen as } \\
\text { relevant" } \\
\text { "Needing reassurance - knowing } \\
\text { that this is what I want to do and } \\
\text { what my career will entail" } \\
\text { "A major preoccupation for my and } \\
\text { many of my friends is whether we } \\
\text { will get a job out of our university } \\
\text { experience". } \\
\text { "We want to get a job, but not all of } \\
\text { my friends or myself may be clear } \\
\text { on our career goals". } \\
\text { "I need to feel like what I am } \\
\text { studying will lead to a fulfilling job" }\end{array}$ & $\begin{array}{l}\text { "In relation to our career goals we think about: } \\
\text { what do I like, what am I good at; what impact } \\
\text { do I want to have what is a fulfilling career" } \\
\text { "I'm working out what a fulfilling job means for } \\
\text { me" } \\
\text { "The way the Lecturer talked about his } \\
\text { experience and engaged us in the course. } \\
\text { This made me look forward to working in the } \\
\text { field" } \\
\text { "I am designing for a better society. This is the } \\
\text { main focus in everything I did" }\end{array}$ \\
\hline \multirow[b]{2}{*}{$\begin{array}{l}\text { Collaboration } \\
\text { 1. Effectively } \\
\text { communicate, } \\
\text { use feedback } \\
\text { from others to } \\
\text { enhance self } \\
\text { and social } \\
\text { awareness } \\
\text { 2. Work with } \\
\text { alumni. }\end{array}$} & Isolated (alone) & Networked (collaborative) \\
\hline & $\begin{array}{l}\text { "If you help me connect, I feel more } \\
\text { engaged," purposeful and } \\
\text { confident" }\end{array}$ & $\begin{array}{l}\text { "I want to talk to people in industry about their } \\
\text { experiences in getting jobs and what happens } \\
\text { in their job and the industry" } \\
\text { "I need people in my life who help me make } \\
\text { decisions on my future" } \\
\text { "Industry connections, networking events help } \\
\text { shape my understanding of the world of work" } \\
\text { "A range of people help shape my career } \\
\text { aspirations and study choices" }\end{array}$ \\
\hline
\end{tabular}

Bates, G.W., Rixon, A., Carbone, A., \& Pilgrim, C. (2019). Beyond employability skills: Developing professional purpose. Journal of Teaching and Learning for Graduate Employability, 10(1), 7-26. 


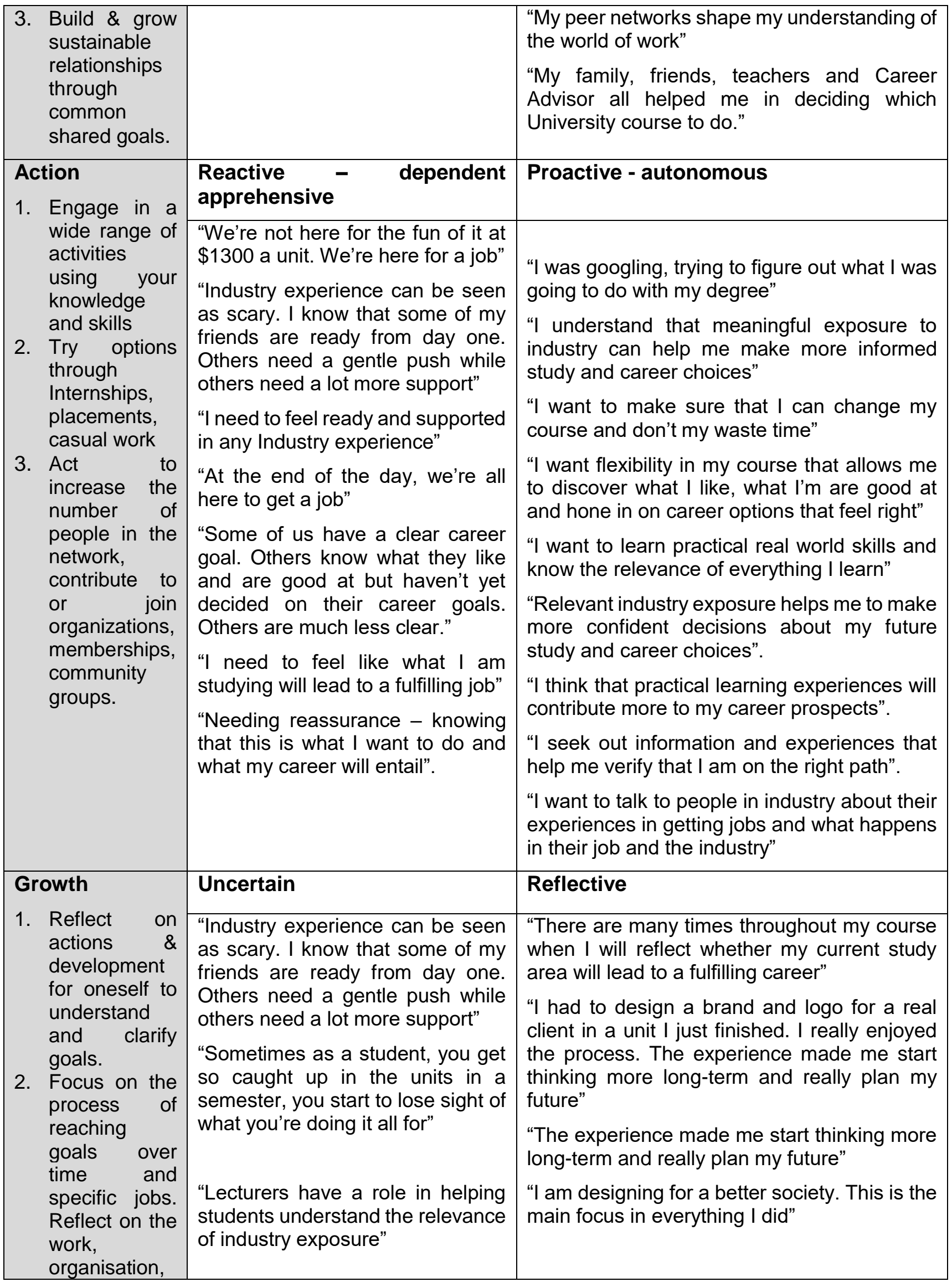

Bates, G.W., Rixon, A., Carbone, A., \& Pilgrim, C. (2019). Beyond employability skills: Developing professional purpose. Journal of Teaching and Learning for Graduate Employability, 10(1), 7-26. 


\begin{tabular}{|c|c|c|}
\hline $\begin{array}{l}\text { knowledge, } \\
\text { skills and } \\
\text { personal } \\
\text { attributes } \\
\text { needed to } \\
\text { succeed } \\
\text { 3. Reflect on } \\
\text { utilise } \\
\text { networks, and } \\
\text { potential } \\
\text { access to } \\
\text { opportunities }\end{array}$ & $\begin{array}{l}\text { "I want to understand how what I } \\
\text { learn is applied in the world of } \\
\text { work" } \\
\text { "We're not here for the fun of it at } \\
\$ 1300 \text { a unit. We're here for a job" } \\
\text { "I want to make sure that I can } \\
\text { change my course and don't waste } \\
\text { my time". }\end{array}$ & $\begin{array}{l}\text { "What I learned about myself is that I don't } \\
\text { want to work in a small business long term. I } \\
\text { don't like no structure. I want to work in big } \\
\text { business". }\end{array}$ \\
\hline
\end{tabular}

Bates, G.W., Rixon, A., Carbone, A., \& Pilgrim, C. (2019). Beyond employability skills: Developing professional purpose. Journal of Teaching and Learning for Graduate Employability, 10(1), 7-26. 